\title{
Effect of Knowledge Sharing and Digital Management to Performance on Ecotourism in Ranong Province, Thailand
}

\author{
Witthaya Mekhum ${ }^{1} \&$ Chonmapat Torasa ${ }^{1}$ \\ ${ }^{1}$ Faculty of Industrial Technology, Suan Sunandha Rajabhat University, Bangkok, Thailand \\ Correspondence: Chonmapat Torasa, Suan Sunandha Rajabhat University, Bangkok, Thailand. E-mail: \\ chonmapat.to@ssru.ac.th
}

Received: July 17, 2020

Accepted: September 4, 2020

Online Published: September 28, 2020

doi:10.5430/rwe.v11n5p481

URL: https://doi.org/10.5430/rwe.v11n5p481

\begin{abstract}
Ecotourism is the combination of ecosystem and tourism. Ecosystem tourism includes travel to destinations where flora, fauna, and cultural heritage are the primary attractions. Present study wants to establish the link between knowledge sharing, information and communication technology (ICT) and ecotourism performance with mediation of tourist attraction and digital management system among employees of ecotourism provider companies in Ranong province of Thailand. Data is collected through questionnaire survey method and via dropdown technique. Partial Least Square (PLS) is used in this study for data analysis. Results indicate that knowledge sharing related to ecotourism and ICT has positive significant impact on ecotourism performance and on tourist attraction and digital management system respectively. Tourist attraction has positive significant impact on ecotourism performance but not mediate the relation. Digital management system mediates the relation and also has the positive significant impact on ecotourism performance. Practitioners should focus on knowledge sharing variable, ICT and digital management system for increasing the ecotourism performance among ecotourism provider companies in Ranong province of Thailand.
\end{abstract}

Keywords: knowledge sharing, ecotourism, tourist attraction, information and communication technology, digital management, ecotourism performance

\section{Introduction}

Ecotourism simple meaning is tour towards ecosystem (Tseng, Lin, Lin, Wu, \& Sriphon, 2019). It means that visit those places which are loaded with natural beauties, natural areas and fragile areas. Ecotourism usually includes travel to termini where flora, fauna, and cultural heritage are the main attractions. Ecotourism is intended to offer tourists an insight into the impact of human beings on the environment and to foster a greater appreciation of natural habitats. It usually done for conserving the environment, natural areas and for the well-being of local peoples. Purpose of ecotourism is to educate the visitors about the ecosystem, natural environment, gather funds for the economic development and for the development of local people who have these types of ecotourism areas. Main purpose of this ecotourism is to tell foreigners about the cultural heritage and teach them how to respect natural heritage of different cultures and also respect other human beings (Cheng, Wong, Wearing, \& McDonald, 2017).

Ecotourism is growing industry in Thailand. Ecotourism is the interactive relationship between ecology, tourism and the economy of Thailand. In present study ecotourism is studied in Ranong province of Thailand. Sustainability of any state is depending on the close integration of economic development, societal development, it's not just the appreciation of physical thing like ecology or ecosystem. It leads towards the deep understanding of benefits of ecotourism for development of any nation (Hausmann, Slotow, Fraser, \& Di Minin, 2017). 


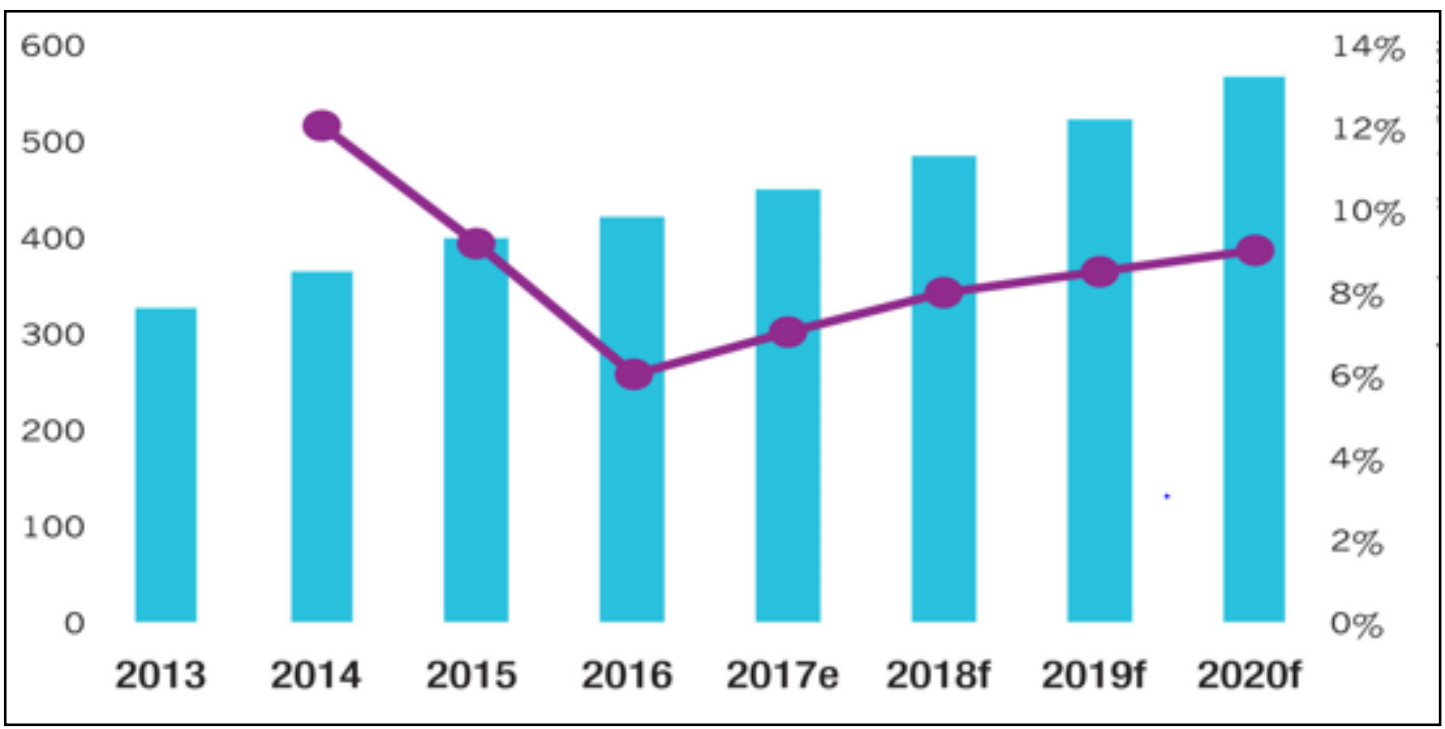

Figure 1. Ecotourism outlook (2019)

Source: Research for the year of 2019

Eco Tourism is a concept covering a wide range of natural realities and is gaining much attraction all over the world. For kingdom of Thailand eco-tourism counts a large in the national economy. During the Asian crisis of 1997 Thailand's eco-tourism was flourished when many traditional and new market segments of Thailand's economy had to accept dramatic slumps in their activities. Meanwhile this development of tourism also faced the challenges of political, ecological and social problems. In the current scenario for ecotourism there are many challenges worldwide. Sentimental issue is one of the largest problem faced to the natural eco system (Jones \& Spadafora, 2017). Industrial growth, increasing transportation, population growth are new challenges to the Thailand eco-tourism. Nature is being disturbed. Now COVID-19 also has affected the eco-tourism and economy of Thailand badly.

Literature evident that performance of ecotourism depends on the foreign tourists visit the ecosystem of host country. Foreign visitors come to visit the ecosystem and came on the ecotourism visit, when they are satisfied from services that are provided to them. Knowledge sharing about the services and about the ecosystem tour from one to another increase the goodwill and foreigner come on ecotourism. Knowledge sharing about the ecotourism and services like digital management system and good information and communication technology that are provided to tourists increase the attraction of other tourists that they come on ecotourism. That increase the performance of ecotourism (Kim \& Park, 2017). Figure 2 showed the link between variables.

Limited studies conducted on this topic. Many studies represent in previous literature that analyze the effect of knowledge sharing related to ecotourism, information and communication technology on ecotourism performance with mediation of tourists' attraction and digital management system Ranong province of Thailand. Literature evident that studies present on ecotourism provider companies has missing the impact of knowledge sharing and ICT (Masud, Aldakhil, Nassani, \& Azam, 2017). Studies that analyzed the impact of knowledge sharing and ICT on ecotourism performance not conducted in ecotourism provider companies of Ranong province of Thailand.

Literature has the gap related to these under-studies' variables population that selected for this study. Conduction of this study is vital addition in previous literature and a considering theoretical contribution. In practical point of view this study gives the contribution in policy making by policy makers that they consider understudies-variables like (ICT, knowledge sharing, tourists' attraction and digital management system) because these variables might be taken positive part in increasing the performance of ecotourism in Ranong province of Thailand.

\section{Literature Review}

Thailand's protected area system (PAS) was established in 1962 when Khao Yai was designated as the country's first national park. Thailand is enriched with tourism resources, not only the manmade resources are very vast, instead Thailand is famous for its natural beauty (Snyman, 2017). There have been nearly 320 units of natural parks and protected areas, more than thousand historical and cultural sites, and many other destinations for tourists in the cities 
and villages as well. Knowledge sharing passing on the true information that has been observed from the real scenarios and has worked a lot on the environmental education and explained the ecotourism are like fragile, pristine and all other undisturbed areas. This research is about the ecotourism of Thailand that how its performance is affected (Ocampo, Ebisa, Ombe, \& Escoto, 2018). Two Independent variables, knowledge sharing related to the ecotourism, and information and communication technology are taken. There is also role of two mediators, tourist attraction and digital management of ecotourism.

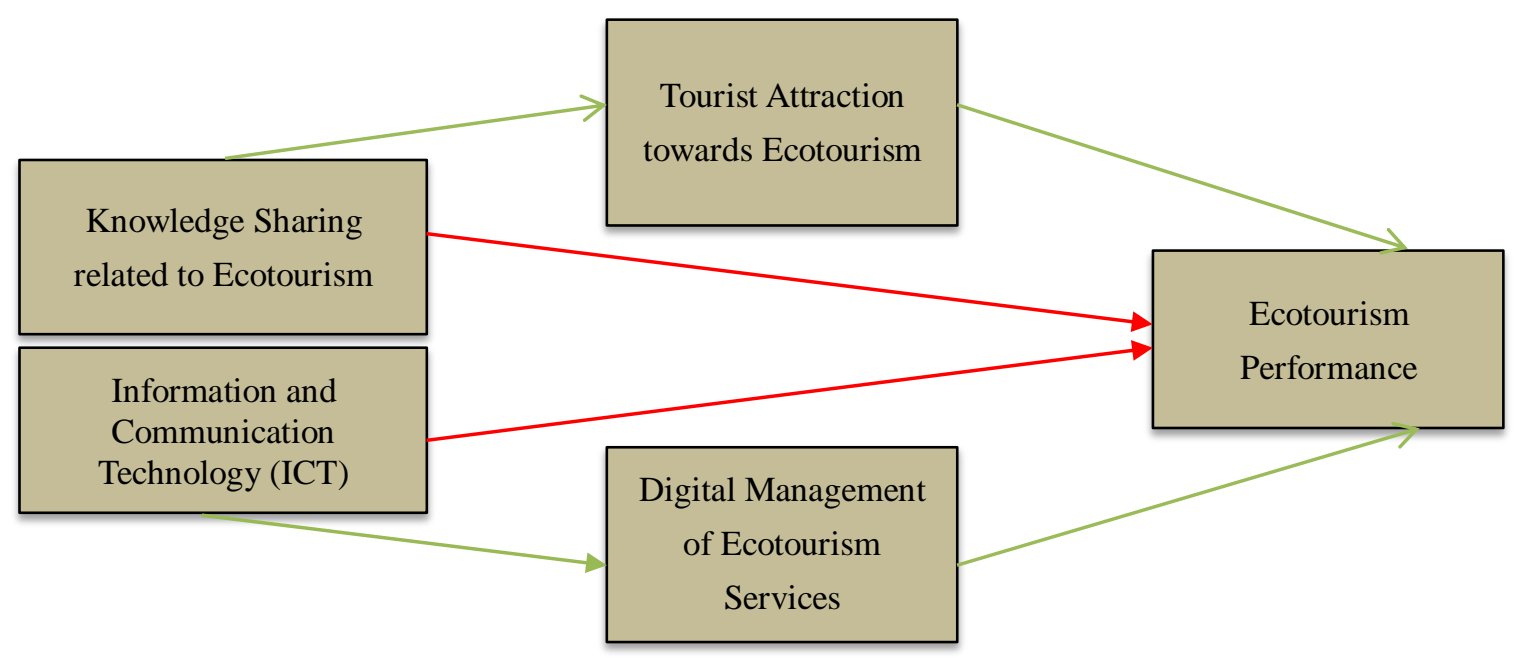

Figure 2. The theoretical framework of the study showing the relationship between variables

\subsection{Knowledge Sharing Related to Ecotourism and Ecotourism Performance}

Ecotourism is flourishing day by day. During the past decade, there have been a number of ecotourism studies in various disciplines to provide a knowledge foundation for sustainable tourism development. Ecotourism is considered the best form of tourism. Ecotourism is about the nature and its healthy effects. In many studies it has been described that ecotourism is related to the health tourism. It gives the relief to traveler without medicine. Many studies have been conducted on the tourism, but eco-tourism needs a lot to explore. Thailand is rich country in this regard. Ranong province of Thailand is considered the hub for tourism and natural places. A study by the rods has mentioned that when tourists visit places, they share their experiences with the other people. Sharing of experiences is the sharing of knowledge (Dahal, 2017b).

Performance of ecotourism is the dependent variable for this research. Many factors which influence the performance of eco-tourism and related knowledge are important. When good experiences are shared it creates the curiosity of doing the same. Studies have shown that sharing of knowledge urges the listener to do the same activity for well-being. Therefore, ecotourism related knowledge sharing can increase the number of tourists for a country. Performance of the eco-tourism can be measured by the number of visitors. Knowledge sharing also helps other tourists as guide for tour. Guide can increase the enjoyment of the tourist which will help to enhance the performance (Dahal, 2017a). As it is evident form a study of (Dahal, 2017a), he has concluded as knowledge sharing study and find out that it can help the other person as an opinion to take the decision of about the same task. As many practitioners and academics concurred that ecotourism is nature-based, and its performance is effected by the knowledge sharing related to their experiences of eco-tourism. In Ranong province of Thailand nature is full and eco-tourism is flourishing. For the performance of eco-tourism, good experiences and knowledge sharing could be key factor. For this research objective in the light of discussed literature it can be concluded as:

H1: Knowledge sharing related to ecotourism has significant positive impact on ecotourism performance.

\subsection{Information and Communication Technology and Ecotourism Performance}

The Internet revolutionizes flexibility in both consumer choice and service delivery processes. Customer now wants to be at more ease to avail the facilities. Because this is the age of competition and there is high level of services are being experienced. Tourist also has become more sophistical and demand high quality product and effective means of service delivery. Effective and high-speed information and communication are now very important for the tourism industry. 
ICT is the extensive term from the information technology (Honey, 2017). It is specified to make the communication system strong and effective for the performance of tourism industry. Eco-tourism is also an emerging trend in the tourism industry and ICT can be applied for its development and betterment.

There are many researches that have described the factor to improve the performance of the tourism industry. National Institute of Tourism \& Hospitality Management has explained the role of ICT in the tourism industry. According to the research Tourism demands technology-driven revolution. E-hospitality, E-air line, E-Travel agencies, E-travel agencies and other same technology can develop the industry and its performance. In eco-tourism trend for technology is the same. People visit the natural places but want information and communication with the pre-visitors. Information and communication technology are the source for the visitor to collect and communicate for the information which later could be positive for them to visit the areas. Satisfaction of the visitor can enhance the performance of ecotourism (Honey, 2018). In this study they have also found the ICT helpful for the ecotourism performance. Kingdom of the Thailand is Eco-tourism carrier. Ranong province is famous for its natural beauty. Eco-tourism is flourishing in the Ranong and been supported with the ICT. According to the eco-tourism blog of Thailand their tourism is open to use the latest technology and ICT for the betterment and ease of visitors. ICTs allow customer -management relations and supply chain management to be combined into a single source that facilitates a variety of operations radical technological developments and their applications can largely contribute to a more effective management of challenges currently faced by our planet. ICT will become interactive through which tourists will also be able to monitor the information posted by others. ICT can increase the safety of eco-tourists by giving early warnings and safety tips for earthquake and flood. These all projects of ICT can help to improve the performance of ecotourism (Hossain \& Islam, 2019). In Ranong province what will be the impact of ICT for ecotourism, from above discussion we can assume that;

H2: Information and communication Technology has significant positive impact on ecotourism performance.

\subsection{Knowledge Sharing Related to Ecotourism and Tourist Attraction and Performance of Ecotourism}

According to Scott and Laws 2006 Knowledge sharing is understood as the practice of capturing and developing individual and collective attraction for an industry for the purpose of developing its performance. Here is the framework designed to find the impact of knowledge sharing on the performance of ecotourism. Studies on the tourism sector have shown the knowledge sharing as a performance indicator. In ecotourism in Ranong if visitors enjoy the fragile and other natural places their experience of visit may attract the others to visit the place. In study of brain 2018 he has given a conclusion that knowledge is a kind of marketing (Marketing, 2016). In another study it is explained as the positive word of mouth through knowledge sharing is a kind of promotion. Visitors in the province Ranong can create attraction for the other tourists by sharing knowledge of the places. To check this link between the knowledge sharing and tourist's attraction hypothesis is given as:

H3: Knowledge sharing related to ecotourism has significant positive impact on tourist attraction.

Now a day's ecotourism is becoming very popular and its attraction can promote its performance for tourists. This article considers the special needs for the attraction of ecotourism that it could be useful for the tourism performance. When there are attractions are created for the ecotourism that help visitor to enjoy and make the services available easy for them this results in positive feedback by the tourist. A study on competitive tourist's destination has mentioned in his work that attraction of the tourism can help to increase the performance of tourism. In Thailand there is much attraction for the tourist, and they are focusing to increase the attraction. Many facilities are being developed in Ranong province which is becoming the source of attraction for tourists. In a research has also given the same conclusion (Rai, 2019). It's a general phenomenon that attraction can positively relate to the performance to find its results in the ecotourism hypothesis can be developed as:

H4: Tourist attraction has significant positive impact on ecotourism performance

In recent years, Thailand has increased its support in developing the natural places at government level it has become generally to attach importance to local tourism and cultural natural resources and make full use of existing resources to develop ecotourism in the country. Ranong Province is also investing for its tourism development. Tourists are being attracted toward these places. Knowledge is being shared through ICT and by other tourists. Knowledge sharing can increase the performance for ecotourism. Tourist attraction is the other factor that has link to the ecotourism performance and knowledge sharing. It can also effect the relation of these two variables. There are few studies on the ecotourism. No study has taken the tourist attraction as mediator in ecotourism performance and knowledge (SALAHI \& NAGHIZADEH, 2016). Literature shows the link of the variables as positive. This will also be the gap for study. To test the mediation role of tourist attraction for Ranong Thailand the hypothesis can be developed as: 
H5: Tourist attraction mediates the relation between knowledge sharing related to ecotourism and performance of ecotourism.

\subsection{Information and Communication Technology, Digital Management System and Ecotourism Performance}

Information and Communication Technologies (ICT) are changing the way we work and play. Such changes are evident in the design, construction and operation of large projects and its implications in the tourism industry has also increased. It is making the way forward for every industry. In Thailand use of ICT and management system has increased the performance of the eco-tourism industry. ICT is the extension of information technology and management system is managing the data and information in a digital way (Adam, Alhassan, \& Afriyie, 2020; Ma'ruf, 2019; Mansoor, Bashir, \& Zubair, 2020; Mbogela, 2019; Omona, van der Weide, \& Lubega, 2010; Rhodes, 2009). Both are complementary for each other. If Technology of information and communication will improve it will make the digital system, more effective and faster. According to the literature and previous studies it has observed that information system in any organization makes its digital system stronger. For the eco-tourism industry of Thailand Ranong, it is to find that how the information and communication technology impact the digital system. Study has revealed that ICT can makes the digital management system more effective (Sawatsuk, Darmawijaya, Ratchusanti, \& Phaokrueng, 2018). Digital record-keeping systems, and the management of digital records is incorporated with ICT strategies. To identify the link hypothesis can be developed

H6: Information and communication technology has positive significant impact on digital management system.

From the above discussion it is obvious that digital management system is also a key factor of the ecotourism in Thailand. A strong management system ensures the quality of services (Mitra, 209; Mohamed, Rasheli, \& Mwagike, 2018; Mose \& Kaboro, 2019; Motuma, 2020; Razzaq, Maqbool, \& Hameed, 2019; Ul-Hameed, Mohammad, \& Shahar, 2018). People who visit Thailand for eco-tourism are conscious about managing information. Digital system has made it much easier to manage the information and other services with the help of technology. When a good system is collaborated with an industry it builds the image of industry. Performance of industry is also can be improved. Thailand has emerged in recent years as one of the leaders in the industry. Ranong province is famous for its digital eco-tourism management. Previous studies have concluded that improving the technology performance of organization can be improved. Another study conducted in Turkey has also given the same conclusion that performance of its tourism has increased with the help of digital management system (Rhodes, 2009; Setsri, 2017). To check this link in the Thailand for Ranong province we can develop hypothesis as:

H7: Digital management system has positive significant impact on ecotourism performance

This proliferation of ICT and digital technologies facilitated the adoption of various innovative approaches in processes and various ICT systems throughout a project lifecycle and across its supply chain (Chai, Hong, \& Teo, 2009). It has great implications for the tourism industry. A research by the international institute of tourism has indicated that without technology development of tourism cannot be imagine. It is helpful in solving the emerging challenges and meeting the competition. Literature is the evident that ICT has a strong relation with the performance of tourism industry. Because a management information system helps a business make decisions and coordinate and analyze information. To develop the performance of ecotourism in Thailand it has been analyzed and that digital management system and information and communication technology both are very important (Hossain \& Islam, 2019). Where ICT can improve the performance it also has direct link with the DMS. Digital management system can mediate this relation between information and communication technology and performance of ecotourism a hypothesis is developed given as:

H8: Digital management system mediates the relation between Information and communication technology and performance of ecotourism.

\section{Research Methodology}

This study wants to measure the increase in performance of ecotourism by using the variables like knowledge sharing related to ecotourism, tourists' attraction, and digital management system and information and communication technology. This study is quantitative in nature as the variables tested by hypothesis formulating and data collection. For data collection respondents of this study were employees working in ecotourism provider companies in Ranong province of Thailand.

Many ecotourism provider companies are working in Ranong province, from this large number of population, sample is selected through the Comrey and Lee (1992), according to him 300 sample size is enough for measuring the variables. Sample is selected by simple random method that is the type of probability sampling technique. This technique is easy and efficient way. Data is collected through questionnaire. Questionnaire include the demographic 
information of respondents and after its questions related to variables are given. These questions adopted from previous studies and designed in 5-point Likert scale way in questionnaire.

After it author itself drop the questionnaire at respondents' place and tell them about the purpose of study and data collection and ensure them that this collected data is only used for research purpose and keep confidential. After two weeks author brought back the filled questionnaires from respondents' place. From 300 questionnaires, deduct the unfilled missing and outliers 230 questionnaires data was used for further analysis.

\section{Data Analysis and Findings}

Table 1 showed the collected data statistics including mean, median and strand deviation. Table also showed that no outliers and missing values were present in this collected data.

Table 1. Data statistics

\begin{tabular}{|c|c|c|c|c|c|c|c|c|c|}
\hline & No. & Missing & Mean & Median & Min & Max & SD & Kurtosis & Skewness \\
\hline KS1 & 1 & 0 & 3.753 & 4 & 1 & 5 & 0.955 & -0.488 & -0.326 \\
\hline KS2 & 2 & 0 & 3.604 & 4 & 1 & 5 & 1.015 & -1.468 & -0.382 \\
\hline KS3 & 3 & 0 & 2.632 & 4 & 1 & 5 & 0.246 & -0.609 & -1.666 \\
\hline KS4 & 4 & 0 & 3.533 & 4 & 1 & 5 & 1.333 & -0.83 & -0.57 \\
\hline KS5 & 5 & 0 & 3.489 & 4 & 1 & 5 & 1.345 & -0.714 & -0.713 \\
\hline KS6 & 6 & 0 & 3.533 & 4 & 1 & 5 & 0.009 & -0.531 & -0.253 \\
\hline ICT1 & 7 & 0 & 2.56 & 4 & 1 & 5 & 1.076 & -0.462 & -0.464 \\
\hline ICT2 & 8 & 0 & 3.604 & 4 & 1 & 5 & 1.239 & -0.634 & -1.626 \\
\hline ICT3 & 9 & 0 & 3.527 & 4 & 1 & 5 & 1.291 & -0.687 & -0.64 \\
\hline ICT4 & 10 & 0 & 3.665 & 4 & 1 & 5 & 0.903 & -1.259 & -0.276 \\
\hline ICT5 & 11 & 0 & 3.632 & 4 & 1 & 5 & 1.023 & -0.465 & -0.423 \\
\hline TA1 & 12 & 0 & 2.478 & 4 & 1 & 5 & 1.353 & -0.774 & -0.664 \\
\hline TA2 & 13 & 0 & 3.665 & 4 & 1 & 5 & 0.885 & -0.111 & -0.342 \\
\hline TA3 & 14 & 0 & 3.61 & 4 & 1 & 5 & 0.009 & -0.419 & -1.417 \\
\hline TA4 & 15 & 0 & 3.5 & 4 & 1 & 5 & 1.098 & -1.199 & -0.64 \\
\hline DM1 & 16 & 0 & 3.549 & 4 & 1 & 5 & 1.17 & -0.361 & -0.66 \\
\hline DM2 & 17 & 0 & 3.401 & 4 & 1 & 5 & 1.157 & -0.55 & -0.572 \\
\hline DM3 & 18 & 0 & 3.516 & 4 & 1 & 5 & 0.208 & -0.574 & -0.548 \\
\hline DM4 & 19 & 0 & 2.621 & 4 & 1 & 5 & 1.136 & -0.39 & -0.574 \\
\hline EP1 & 20 & 0 & 3.56 & 4 & 1 & 5 & 1.076 & -0.11 & -1.678 \\
\hline EP2 & 21 & 0 & 3.725 & 4 & 1 & 5 & 1.301 & -1.514 & -0.79 \\
\hline EP3 & 22 & 0 & 3.659 & 4 & 1 & 5 & 0.197 & -0.297 & -0.73 \\
\hline EP4 & 23 & 0 & 3.714 & 4 & 1 & 5 & 1.308 & -0.809 & -0.617 \\
\hline EP5 & 24 & 0 & 3.544 & 4 & 1 & 5 & 1.102 & -0.428 & -0.485 \\
\hline
\end{tabular}

DM: Digital management, EP: Ecotourism Performance, ICT: information and communication Technology, KS: Knowledge Management, TA: Tourist Attraction

After removing the outliers and missing values, Smart PLS used on data analysis. Below given Figure 3 generated reliability and validity. Reliability was measured from factor loadings, value of Alpha, composite reliability and average variance extracted (AVE). All values were in accepted range and showed in Table 2 and Table 3 (Henseler, Ringle, \& Sinkovics, 2009). In next, Table 4 is given, value of HTMT is highlighted. This value was used for analyzing the validity of collected data. 


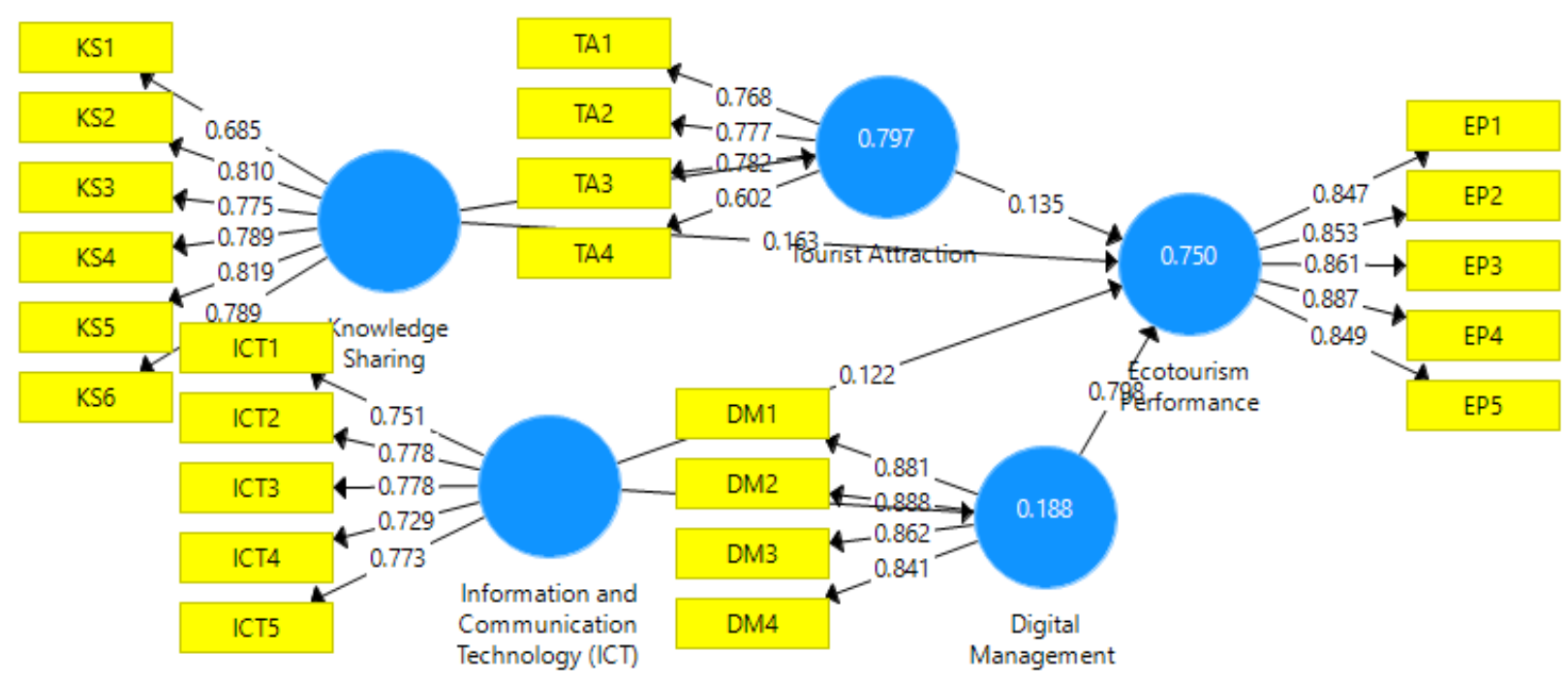

Figure 3. Measurement model

Table 2. Factor loadings

\begin{tabular}{|c|c|c|c|c|c|}
\hline & $\begin{array}{c}\text { Digital } \\
\text { Management }\end{array}$ & $\begin{array}{c}\text { Ecotourism } \\
\text { Performance } \\
\end{array}$ & (ICT) & $\begin{array}{l}\text { Knowledge } \\
\text { Sharing }\end{array}$ & $\begin{array}{c}\text { Tourist } \\
\text { Attraction } \\
\end{array}$ \\
\hline DM1 & 0.881 & & & & \\
\hline DM2 & 0.888 & & & & \\
\hline DM3 & 0.862 & & & & \\
\hline DM4 & 0.841 & & & & \\
\hline EP1 & & 0.847 & & & \\
\hline EP2 & & 0.853 & & & \\
\hline EP3 & & 0.861 & & & \\
\hline EP4 & & 0.887 & & & \\
\hline EP5 & & 0.849 & & & \\
\hline ICT1 & & & 0.751 & & \\
\hline ICT2 & & & 0.778 & & \\
\hline ICT3 & & & 0.778 & & \\
\hline ICT4 & & & 0.729 & & \\
\hline ICT5 & & & 0.773 & & \\
\hline KS1 & & & & 0.685 & \\
\hline $\mathrm{KS} 2$ & & & & 0.81 & \\
\hline KS3 & & & & 0.775 & \\
\hline KS4 & & & & 0.789 & \\
\hline KS5 & & & & 0.819 & \\
\hline KS6 & & & & 0.789 & \\
\hline TA1 & & & & & 0.768 \\
\hline TA2 & & & & & 0.777 \\
\hline TA3 & & & & & 0.782 \\
\hline TA4 & & & & & 0.602 \\
\hline
\end{tabular}

DM: Digital management, EP: Ecotourism Performance, ICT: information and communication Technology, KS: Knowledge Management, TA: Tourist Attraction 
Table 3. Alpha, CR and AVE

\begin{tabular}{lcccc} 
& Alpha & rho_A & $\begin{array}{c}\text { Composite } \\
\text { Reliability }\end{array}$ & AVE \\
\hline Digital Management & 0.891 & 0.891 & 0.924 & 0.754 \\
Ecotourism Performance & 0.912 & 0.913 & 0.934 & 0.739 \\
Information and Communication Technology (ICT) & 0.82 & 0.824 & 0.874 & 0.581 \\
Knowledge Sharing & 0.87 & 0.871 & 0.902 & 0.607 \\
Tourist Attraction & 0.714 & 0.724 & 0.824 & 0.542 \\
\hline
\end{tabular}

DM: Digital management, EP: Ecotourism Performance, ICT: information and communication Technology, KS: Knowledge Management, TA: Tourist Attraction

Table 4. HTMT

\begin{tabular}{cccccc}
\hline Digital & Ecotourism & & Knowledge & Tourist \\
Management & Performance & (ICT) & Sharing & Attraction \\
\hline
\end{tabular}

Digital Management

Ecotourism Performance

Information and Communication

Technology (ICT)

Knowledge Sharing

Tourist Attraction
0.753

$0.503 \quad 0.496$

$0.467 \quad 0.446 \quad 0.796$

DM: Digital management, EP: Ecotourism Performance, ICT: information and communication Technology, KS: Knowledge Management, TA: Tourist Attraction

Below given Figure 4 of structural model assessment showed the link between given variables and tested the hypothesis that made in literature part of this study (Dahri, Hameed, Nawaz, Sami, \& Bux Shah, 2019; Hair, Hollingsworth, Randolph, \& Chong, 2017; Zahra, Hameed, Fiaz, \& Basheer, 2019). All hypothesis of direct link between knowledge sharing, ICT, tourist attraction, digital management system and ecotourism performance was accepted. T-values are greater than 1.96 and beta values are positive. It is revealed positive significant impact. All values of direct effect are showed in Table 5.

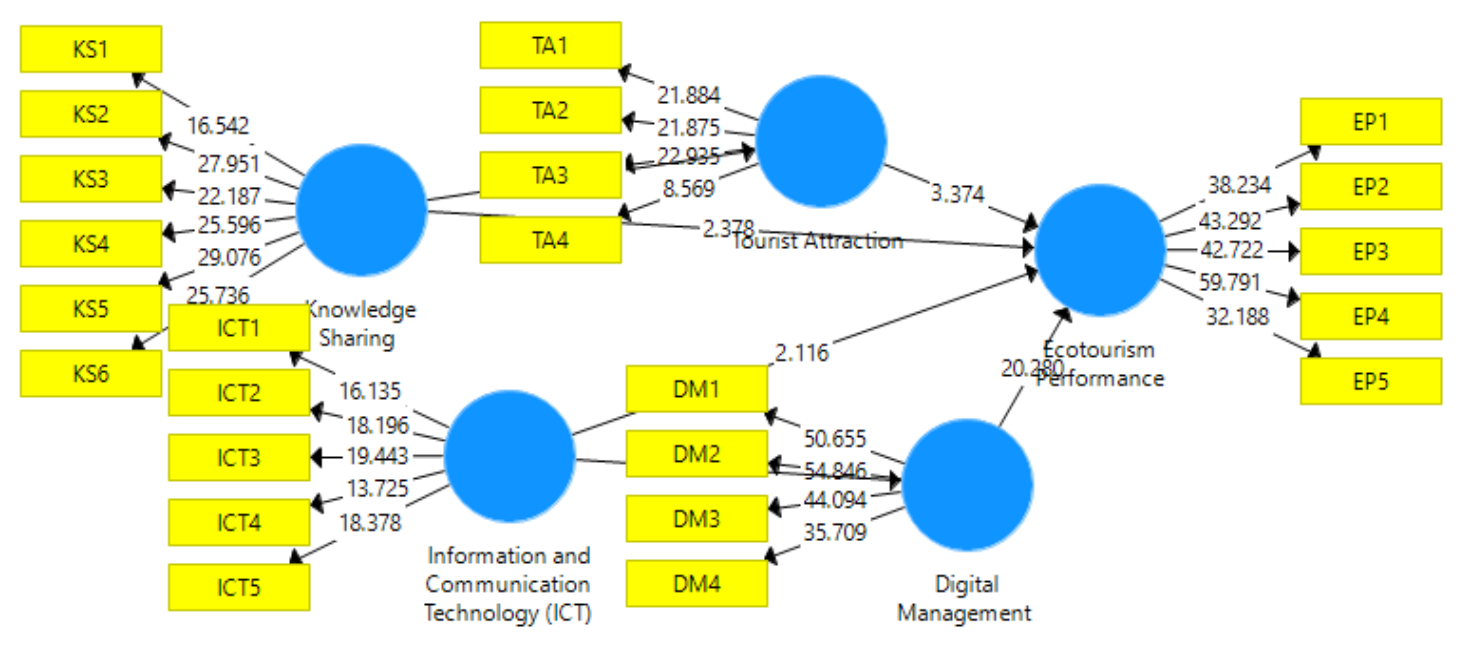

Figure 4. Structural model 
Table 5. Direct effect results

\begin{tabular}{lccccc}
\hline & & & & & \multicolumn{1}{c}{$\begin{array}{c}\text { T } \\
\text { Values }\end{array}$} \\
\hline $\begin{array}{l}\text { Digital Management -> Ecotourism Performance } \\
\text { Information and Communication Technology (ICT) -> }\end{array}$ & 0.798 & 0.793 & 0.039 & 20.28 & 0 \\
Digital Management & 0.434 & 0.444 & 0.067 & 6.436 & 0 \\
Information and Communication Technology (ICT) -> & & & & & \\
Ecotourism Performance & 0.122 & 0.121 & 0.057 & 2.116 & 0.039 \\
Knowledge Sharing -> Ecotourism Performance & 0.163 & 0.172 & 0.07 & 2.378 & 0.031 \\
Knowledge Sharing -> Tourist Attraction & 0.893 & 0.894 & 0.014 & 62.535 & 0 \\
Tourist Attraction -> Ecotourism Performance & 0.135 & 0.148 & 0.04 & 3.374 & 0.002 \\
\hline
\end{tabular}

DM: Digital management, EP: Ecotourism Performance, ICT: information and communication Technology, KS:

Knowledge Management, TA: Tourist Attraction

Figure 4 of Structural model assessment and below given Table 6, also showed the indirect mediation effect of digital management system and tourist attraction. $\mathrm{T}$ value and beta values revealed that digital management system mediates the relationship between ICT and ecotourism performance. But tourist attraction not mediates the relation between knowledge sharing and ecotourism performance. Mediation of digital management system showed in Figure 5.

Table 6. In-direct effect results

\begin{tabular}{|c|c|c|c|c|c|}
\hline & $(\mathbf{O})$ & (M) & SD & $\begin{array}{c}\mathbf{T} \\
\text { Statistics }\end{array}$ & $\begin{array}{c}\mathbf{P} \\
\text { Values }\end{array}$ \\
\hline $\begin{array}{l}\text { Information and Communication Technology (ICT) -> } \\
\text { Digital Management }->\text { Ecotourism Performance } \\
\text { Knowledge Sharing }>\text { Tourist Attraction -> Ecotourism }\end{array}$ & 0.346 & 0.352 & 0.056 & 6.183 & 0 \\
\hline Performance & 0.12 & 0.132 & 0.088 & 1.366 & 0.173 \\
\hline
\end{tabular}

DM: Digital management, EP: Ecotourism Performance, ICT: information and communication Technology, KS:

Knowledge Management, TA: Tourist Attraction

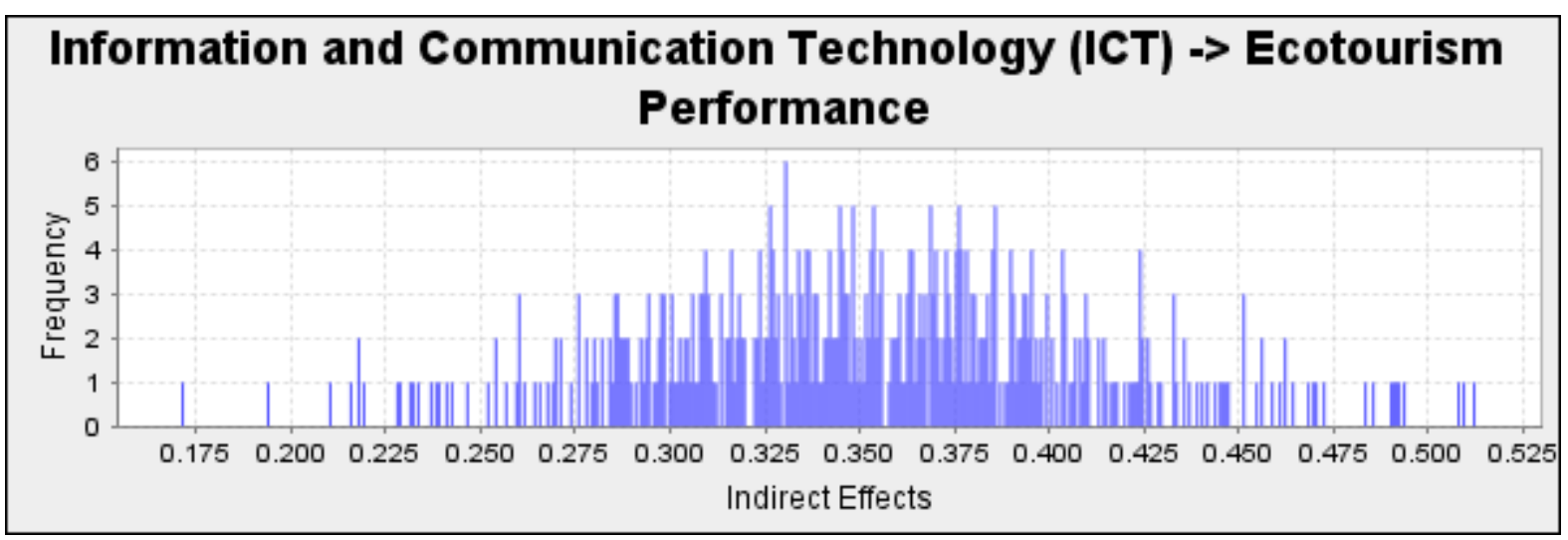

Figure 5. Indirect effect of digital marketing between ICT and ecotourism performance

$\mathrm{R}$ square $\left(\mathrm{R}^{2}\right)$ value is 0.75 . It means that $75 \%$ change in ecotourism performance is substantial as per the instructions of Chin (1998) and it is due to the knowledge sharing, ICT, tourist attraction and also due to digital management system.

\section{Discussion}

Present study established the link between knowledge sharing, ICT, tourist attraction and digital management system on ecotourism performance. Respondents of this study are employees working in ecotourism provider companies in 
Ranong province of Thailand. Data is collected through questionnaire and dropdown method. Data was cross-sectional and study is quantitative. For analyzing the data Smart PLS is used on it.

Results that generated from Smart PLS showed that, knowledge sharing related to ecotourism has significant positive impact on ecotourism performance. As increase in knowledge sharing by tourists to one another and also in their host country increase the foreigner tourists' visits and ecotourism performance increase (Bluwstein, 2017). Like knowledge sharing increase tourism attraction and interest to visit the place is increased. And an increase in tourist attraction towards visiting the place increases the performance of ecotourism. Like knowledge sharing, tourist attraction has positive significant impact on ecotourism attraction but not mediates the relation between knowledge sharing and ecotourism performance (Aversa, Petrescu, Apicella, \& Petrescu, 2017).

Results also revealed that ICT has positive significant impact on ecotourism. As ecotourism provider companies focus on their information and communication system it increases the performance of ecotourism. Increase in information and communication between ecotourism provider employees and tourists increase the performance of ecotourism. Digital management system of services that provided to tourists' increase the performance of ecotourism (Ban \& Ramsaran, 2017). Digital management system also mediates the relationship between ICT and ecotourism performance in Ranong province of Thailand.

\section{Conclusion}

This study wants to study the link between knowledge sharing related to ecotourism performance, information and communication technology on ecotourism performance with the mediation of tourists' attraction and digital management system. Results revealed that knowledge sharing related to ecotourism performance has positive significant impact on tourists' attraction and ecotourism performance. Tourists' attraction also has positive significant impact on ecotourism performance but not mediates the relation between knowledge sharing and ecotourism performance. Information and communication technology (ICT) have positive significant impact on digital management system and also on the ecotourism performance. Digital management system has positive significant impact on ecotourism performance, and it mediates the relation between information and communication technology and ecotourism performance. Ecotourism provider companies' policy makers should focus on the knowledge sharing and ICT for improving performance of ecotourism in Ranong province of Thailand.

\section{Implications}

This study examines that link between knowledge sharing related to ecotourism performance, information and communication technology on ecotourism performance with mediation of tourists' attraction and digital management system among employees working in ecotourism provider companies in Ranong province of Thailand is missing in previous literature. By studying these variables, this study has theoretical implications in previous literature. Ecotourism is fastest growing industry in Ranong province of Thailand but facing some challenges related to their performance. For increasing the performance of ecotourism provider companies, policy makers should focus the knowledge sharing as good knowledge about ecosystem is shared among people, due to this tourists' attraction increase and that increase the performance. This study suggested that focus on digital management system for tourists and give them information communication has significant role to promote ecotourism.

\section{References}

Adam, I. O., Alhassan, M. D., \& Afriyie, Y. (2020). What drives global B2C E-commerce? An analysis of the effect of ICT access, human resource development and regulatory environment. Technology Analysis \& Strategic Management, 1-16.

Aversa, R., Petrescu, R. V., Apicella, A., \& Petrescu, F. I. (2017). Modern transportation and photovoltaic energy for urban ecotourism. Transylvanian Review of Administrative Sciences, Special(2017), 5-20.

Ban, J., \& Ramsaran, R. R. (2017). An exploratory examination of service quality attributes in the ecotourism industry. Journal of Travel \& Tourism Marketing, 34(1), 132-148.

Bluwstein, J. (2017). Creating ecotourism territories: Environmentalities in Tanzania's community-based conservation. Geoforum, 83, 101-113.

Chai, C. S., Hong, H.-Y., \& Teo, T. K. G. (2009). Singaporean and Taiwanese pre-service teachers' beliefs and their attitude towards ICT use: A comparative study. The Asia-Pacific Education Researcher, 18(1), 117-128.

Cheng, M., Wong, I. A., Wearing, S., \& McDonald, M. (2017). Ecotourism social media initiatives in China. Journal of Sustainable Tourism, 25(3), 416-432. 
Chin, W. W. (1998). The partial least squares approach to structural equation modeling. Modern Methods for Business Research, 295(2), 295-336.

Comrey, A., \& Lee, H. (1992). A First Course in Factor Analysis (2nd ed.). Lawrence Earlbaum Associates. Publishers: Hillsdale, New Jersey.

Dahal, R. (2017a). Impact of Political Developmenton Tourism Industry In Nepal (1990-2015 Ad). Central Department of Political Science.

Dahal, R. (2017b). Prospects of Eco-Tourism In Nepal. Central Department of Rural Development Tribhuvan University, Kathmandu.

Dahri, A. S., Hameed, W. U., Nawaz, M., Sami, A., \& Bux Shah, S. K. (2019). Nurses' Job Satisfaction is Burned out by their Leaders and Stress. Journal of Managerial Sciences, 13(2).

Hair, J., Hollingsworth, C. L., Randolph, A. B., \& Chong, A. Y. L. (2017). An updated and expanded assessment of PLS-SEM in information systems research. Industrial Management \& Data Systems, 117(3), 442-458.

Hausmann, A., Slotow, R., Fraser, I., \& Di Minin, E. (2017). Ecotourism marketing alternative to charismatic megafauna can also support biodiversity conservation. Animal Conservation, 20(1), 91-100.

Henseler, J., Ringle, C. M., \& Sinkovics, R. R. (2009). The use of partial least squares path modeling in international marketing. New challenges to international marketing (pp. 277-319). Emerald Group Publishing Limited.

Honey, S. (2017). Socio-Economic Impact of Ecopark: A study on Sitakunda Ecopark.

Honey, S. (2018). Socio-Economic Impact of Ecopark: A study on Sitakunda Ecopark.

Hossain, M. K., \& Islam, S. (2019). An Analysis of Destination Attributes to Enhance Tourism Competitiveness in Bangladesh. African Journal of Hospitality, Tourism and Leisure, 8(2).

Jones, G., \& Spadafora, A. (2017). Creating Ecotourism in Costa Rica, 1970-2000. Enterprise \& Society, 18(1), 146-183.

Kim, K.-H., \& Park, D.-B. (2017). Relationships among perceived value, satisfaction, and loyalty: Community-based ecotourism in Korea. Journal of Travel \& Tourism Marketing, 34(2), 171-191.

Ma'ruf, A. (2019). Sharia finance literacy and determinants on creative economy. International Journal of Economics, Business and Management Studies, 6(1), 19-25.

Mansoor, S., Bashir, S., \& Zubair, M. (2020). Is bt gene cotton adoption paying off farmers in Pakistan?. Asian Development Policy Review, 8(1), 30-41.

Marketing, G. (2016). International Journal of Trend in Scientific Research and Development (IJTSRD).

Masud, M. M., Aldakhil, A. M., Nassani, A. A., \& Azam, M. N. (2017). Community-based ecotourism management for sustainable development of marine protected areas in Malaysia. Ocean \& Coastal Management, 136, 104-112.

Mbogela, C. (2019). An empirical examination on trade openness and economic growth nexus in Africa. Asian Journal of Economics and Empirical Research, 6(1), 1-15.

Mitra, S. (209). A neoclassical approach to behavioral economics. International Journal of Economics, Business and Management Studies, 6(1), 1-18.

Mohamed, B. M., Rasheli, G. A., \& Mwagike, L. R. (2018). Marginal effects of factors influencing procurement records management: A survey of selected procuring entities in Tanzania. International Journal of Social and Administrative Sciences, 3(1), 22-34.

Mose, N., \& Kaboro, J. (2019). Does inflation rate convergence spur exchange rate volatility? Empirical evidence from Sub-Saharan Africa. Asian Journal of Economic Modeling, 7(2), 95-109.

Motuma, F. Y. (2020). Decomposition of rural poverty by demographic context of rural households: The case from kola agro-ecological zone of Humbo Woreda, Southern Ethiopia. Asian Development Policy Review, 8(1), 1-6.

Ocampo, L., Ebisa, J. A., Ombe, J., \& Escoto, M. G. (2018). Sustainable ecotourism indicators with fuzzy Delphi method-A Philippine perspective. Ecological Indicators, 93, 874-888.

Omona, W., van der Weide, T., \& Lubega, J. (2010). Using ICT to enhance knowledge management in higher education: A conceptual framework and research agenda. International Journal of Education and Development 
using ICT, 6(4), 83-101.

Rai, B. M. (2019). Impact of Homestay on Farmers'Livelihood in Gangtey Valley.

Razzaq, S., Maqbool, N., \& Hameed, W. U. (2019). Factors Effecting The Elasticity Of Micro Credit Demand In Southern Punjab, Pakistan. International Journal of Social Sciences and Economic Review, 1(2), 46-53.

Rhodes, J. (2009). Using actor-network theory to trace an ICT (telecenter) implementation trajectory in an African women's micro-enterprise development organization. Information Technologies \& International Development, 5(3), 1-20.

Salahi, B., \& Naghizadeh, R. (2016). Assessment of Ecological Power for Locating Tourist Villages. Journal of Gastronomy Hospitality and Travel, 2(2), 120-133.

Sawatsuk, B., Darmawijaya, I. G., Ratchusanti, S., \& Phaokrueng, A. (2018). Factors determining the sustainable success of community-based tourism: Evidence of good corporate governance of Mae Kam Pong Homestay, Thailand. International Journal of Business and Economic Affairs, 3(1), 13-20.

Setsri, P. (2017). The Pattern of Elderly Health Tourism in Bangkok, Thailand. International Journal of Social Science and Humanity, 7(2).

Snyman, S. (2017). The role of private sector ecotourism in local socio-economic development in southern Africa. Journal of Ecotourism, 16(3), 247-268.

Tseng, M.-L., Lin, C., Lin, C.-W. R., Wu, K.-J., \& Sriphon, T. (2019). Ecotourism development in Thailand: Community participation leads to the value of attractions using linguistic preferences. Journal of cleaner production, 231, 1319-1329.

Ul-Hameed, W., Mohammad, H., \& Shahar, H. (2018). Microfinance institute's non-financial services and women-empowerment: The role of vulnerability. Management Science Letters, 8(10), 1103-1116.

Zahra, M., Hameed, W. U., Fiaz, M., \& Basheer, M. F. (2019). Information Technology Capability a Tool to Expedite Higher Organizational Performance. UCP Management Review (UCPMR), 3(1), 94-112.

\section{Copyrights}

Copyright for this article is retained by the author(s), with first publication rights granted to the journal.

This is an open-access article distributed under the terms and conditions of the Creative Commons Attribution license (http://creativecommons.org/licenses/by/4.0/). 